\title{
THE GRADUATES' NATIONAL MOVEMENT IN SUDAN, 1918-1944
}

\author{
Nowar Gaffer
}

\begin{abstract}
This article discusses the Graduates' National Monement in Sudan between 1918-1944. The first part of the article examines the emergence of the Graduates' club in 1918, its various cultural activities as well as the impact of these cultural activities on the emergence of the philosoplical thoughts of the Graduates which were exhibited in their lectures at the chub and in their articles published in national journals. This is followed by an analysis of the White flag league movement and its impact on the Graduates' National Movement. The third part examines the rise of the graduates' literary societies and their amalganation in these societies to instigate the concepts of patriotism and nationalism anong the members of the educated elite in that plase. The fourth part considers the impact of the 1936 agreenent on the Graduates' monement and their rally to forn a stronger organization of their own to threaten the colonial powers in their country. The final section drans some conclusion from this study.
\end{abstract}

\section{Introduction}

After the end of the Mahdist state in 1899, Sudan was brought under a joint administration of the Anglo Egyptian forces, known as the Condominium. The new administration took effect after the signing of its conventions by the British consul general in Egypt Lord Cromer and the Egyptian foreign minister Boutras Ghali on 19th January 1899. Immediately after the signing of the agreement Lord Kitchener the commander-in-chief of the invading army was appointed the Governor-General of Sudan. All the high posts in the administration were given to British officers, while middle minor posts, widely known as mamur, were occupied by Egyptian officials. At the time of its 
origination, the Condominium administration paid enormous attention to the maintenance of the organization, where the limited resources of the country which depended on Egyptian revenues, were spent in consolidating security.

Although limited financial resources were available, the condominium administrators set on inaugurating a few educational institutes with the aim of creating a Sudanese-educated class that would probably serve as clerks in the new government offices and fill some minor posts in the administrative machinery. The newly built institutions included primary and secondary schools as well as the Gordon Memorial College, with the aim that the college would function to train its students to be clerks, officials, artisans and technicians. Gordon Memorial College also provided its students with literal knowled ge in Arabic and English languages. This literal information was exhibited in extracurricular activities, thence the college teachers supervised their students and aided them to hold cultural nights in which capable students were trained in both Arabic and English languages. All these activities had indirectly encouraged their group spirit and gave them the knowledge and confidence to articulate and disseminate nationalist ideologies. These cultural gatherings familiarized students of Gordon Memorial College with European languages, cultures and British politicians, also added to this, the fact that their knowledge in the Arabic language which was exercised in the reading of Arabic journals, political poetry and the philosophy of Arab nationalism had promoted their understanding for Arab nationalism. This familiarity with European and Arab politics encouraged them to establish a graduates' club, with the objective of promoting fraternity among the graduates. Thus, in 1917 a preparatory committee was elected and funds were raised to establish such a great society.

\section{Graduates' Club As The First Advocate of Modern Sudanese Nationalism}

On 18th May 1918, the Sudan Schools' Graduates' club was opened in Omdurman under the surveillance of a Gordon's College warden Mr. Simpson, who stated in his speech at the opening ceremony of the club, that it would play an effective and prominent role in Sudan. Since its establishment the club paid enormous attention to the social activities like the celebration of religious occasions and other similar events that were traditionally celebrated by the Sudanese.' However, these social activities were considered by the politically ambitious graduates as limited, since they wished that their club would be more active in the national stratum and become an advocate of anti- colonialism in 
Sudan. The Graduates viewed their club as a place of exchanging idea therefore they exhibited discussions about the conditions in Sudan and particularly its political fate. The dominance of the cultural trend upon the Graduates' activities led to the appearance of various philosophers and journalists. They resembled at the Graduates' club two main groups' directive each of them had its own respective philosophy in their approaches to Sudan's political situation. ${ }^{2}$

The first group believed in the idea of 'the Sudan for Sudanese', which originated from the thought of the first Sudanese journalist, Hussein Sharif. Sharif propagated for his ideas in four articles which were published in the Sudanese newspaper Had rat Al-Sudan ${ }^{3}$ His writings encouraged the maintenance of limited interactions with the British government to allow for Sudanese training in modern aspects yet he advocated British departure after this was achieved. On the other hand, Sharif had resented unity with Egypt, on the assumption that it would hinder the sole rule of the Sudanese of their country. Adopters of the Sudan for Sudanese notion were known as the Shawgists, as a result of their following the nationalist veteran Mohammed Ali Shawgi. ${ }^{4}$ This group also had strong ties with the leader of the Ansar sect, Sayyid Abd Al-Rahman Al-Mahdi, and under his patronage they deliberately controlled the Graduates' club committees between the years of 1920$1933 .^{5}$

Another faction of the Graduates was completely influenced by the thought of Egyptian nationalists, and they called for Sudan's unity with Egypt under the Egyptian crown. Unionists believed that unity with Egypt was important to secure the stability in Sudan and they also assumed that the unity between the two countries was natural, due to the strong cultural and geographical bondage that related both the Egyptians and Sudanese. ${ }^{6}$ In the Graduates' club this group was commonly known as the Feelists since they followed the club's member Ahmed El- Sayyid Al-Feel unlike their counterparts the Shawgists they did not appreciate ties with the religious sects, although most of them were originally from families that had been loyal to the Khatminya sect and its leader Sayyid Ali Elmirghani.? Both factions at the Graduates' club were quite involved in national politics and followed with genuine interest global political events which sentiments were utilized in broadening the Graduates' political visualization and myth. ${ }^{8}$ Club members also followed admiringly the events of the 1919 Egyptian revolution and managed to grasp some of its national principles that called for the rejection of martial law and the exclusion of the British rule from Egypt. ${ }^{9}$

The effects of this revolution upon the Sudanese were many. ${ }^{10}$ They instilled revolutionary sentiments among them, and facilitated 
the path of establishing the first secret Sudanese partythe league of Sudanese union in 1922. The union included Sudanese like Suleiman Kisha, Babiker Al-Qabbani, Mohammed Salih Al-Shingiti and Obaid Haj Al-Amin. Since its establishment, the union advocated issuing proclamations that included anti- British views and vowed criticism for religious sects' leaders on the basis that they accommodated colonial administration. On the other hand, the league acknowledged the unity between Sudan and Egypt and resented any form of separation between the two countries. In 1923, the leagues' president Obaid Haj Al-Amin" assumed that verbal criticism was not enough to secure the overthrow of the colonial administration, whereby as a result of this he abandoned the union and joined together with some aides the White flag league. The White flag league was mainly composed of military officers like Ali Abd Al-Latif and Abdel Fadil Elmaz, who genuinely opposed the British administration and awaited the right moment to move against it. In $1922 \mathrm{Ali}$ Abdel Al-Latif published an article, in which he urged the implementation of economic and political reforms in Sudan. ${ }^{12}$

The article was considered an incitement and its writer was imprisoned as the consequence, after being released from prison, Ali $\mathrm{Abd} \mathrm{Al}$-Latif and some enthusiastic Sudanese nationalists, intensified their national meetings and decided to revolutionize against the colonial regime

\section{White Flag League Movement and 1924 Revolution}

The 1924 movement of the military officers, and some graduates who had been members of the Graduates' club in Omdurman were commonly recognized as the first organized national movement led by Sudanese nationalists against the British administration. In addition to the distribution of seditious circulars, the revolution consisted of urban demonstrations that started in June 1924, when the military graduates roamed the streets of Khartoum, calling for a long life for Egypt, its king Fuad and requested the downfall of the colonial rule. These revolutionary sentiments were soon spreading all over the main cities in Sudan like Omdurman, Wad Medani, Al-Ubaid and Port Sudan, where the demonstrators carried anti - colonial slogans and called for the downfall of the British. As a result of these extensive anti-colonial allegations, the British administration imprisoned Ali Abd Al-Latif on the $4^{\text {th }}$ July 1924, an instigating act which triggered more demonstrations during the months of July and August. Following Abd Al-Latif imprisonment, the revolutions' leadership was then handed to Obaid Haj Al-Amin. 
This marked the end of the peaceful combat against colonialism and the beginning of a strong resistance, challenge and confrontation to the regime. The mood of political discussions and operations, did not last for long since it was soon changed into military confrontations. The militants were soon joined by the entire army, who decided to take the revolutionists' side favoring the national role upon the loyalty to the colonial administration. On the $9^{\text {th }}$ August 1924, military school students roamed around the streets of Khartoum rioting against the colonial regime and expressing their support for the White Flag League. ${ }^{13}$ The militants who raised the green Egyptian flag and the pictures of King Fuad $1^{14}$ of Egypt visited the main mosque in Khartoum and Ali Abd Al-Latifs' residence where they supported his family with some ammunition. They then moved towards the Khartoum North prison, calling for a longer life for Ali Abd Al-Latif, who was serving time in prison. Revolutionists also managed to distribute ammunitions among the surrounding civilians. ${ }^{15}$ Due to the civilians' involvement in the ongoing events, fifty one participants in the riots were joined together by the revolutionists in most main cities in Sudan, also accompanied this time by workers in the railway service and other governmental institutions. ${ }^{16}$

This spread of revolutionary attitude was a causal factor in the surge of the revolutionary events, whereby on $27^{\text {th }}$ November 1924 a group of Sudanese mobs moved towards the military school, broke its ammunition stores and walked throughout all the paths to Khartoum North after passing in front of the Ministry of War. Before they reached their designated destination they were immediately surrounded by the British forces who ordered them to repel to their barracks; however their refusal to surrender exposed them to gunfire and they were finally killed. Modern historians on the other hand related its causes to economic hardships, job dissatisfaction and generational conflict between the young educated classes and their elders. ${ }^{17}$ To most of the Sudanese writers, the events of 1924, resembled a definite revolution and regarded it as an early manifestation of Wataniyya, or nationalism, ${ }^{18}$ whilst to modern historian the revolution was a landmark in the development of anti-colonial nationalism, and the first spark of organized political struggle for combatting the colonial rule in Sudan. ${ }^{19}$

The British administration blamed two groups ${ }^{20}$ for thrashing up trouble in 1924: the Egyptian officials and the non-Arab Sudanese. Colonial administrators in Khartoum dealt with the first group by evicting 118 Egyptians civilian officials-including many school teachers and also ordered the exile of the Egyptian military officers and banned the circulation of Egyptian newspapers ${ }^{21}$ in Sudan. As for the second group, they were harshly dealt with since the ringleaders 
of the revolution were either shot or sentenced to jail. The British administration also dismantled the militant participants from battalions of the Egyptian army in which the Southern Sudanese inhabitants of the Nuba mountains had been particularly prominent, established a "Sudan defense force", with locally - recruited base contingents, in January $1925 .{ }^{22}$ In order to render the possibility of revolutionary resurgence similar to the patriotic movement of 1924, the British administration introduced its policy of indirect rule with the main aim, eliminating the authorities given to the ed ucated group. As stated by one historian, 'the Graduates of Gordon Memorial College fell out of service among British officials and lost ground versus rural notables. ${ }^{23}$

As a result of implementing the indirect rule the administrative authority was vested in the hands of tribal leaders who gained authority over local police forces and issued their judgments upon matters according to the customary law. The indirect method of administration was strictly applied in 1926, where during the Governor-Generalship of Sir James Maffey who issued in 1927 Powers of Sheiklts Ordinance, the tribal leaders were conferred prominent positions in the administration by being allowed legislative authorities in 1933. During the period between 1926-1934, the educated elite was completely excluded from all sorts of participation in the ad ministration the rush to build educational institutes also witnessed an obvious drop, while the numbers of students sent overseas for studies had also been reduced..$^{24}$

\section{Graduates' Movement1925-1936}

As a result of this severe blow for their quality and national ambition after the revolution of 1924, the educated elite turned towards cultural activities and reading groups. They had hoped to broaden their perception, since they believed that the failure of 1924 was primarily due to their lack of knowledge. In order to educate themselves, graduates from the same professional or residential background formed small study circles and literary societies, whose members met in private houses to avoid the observation of the British administration..$^{25}$ At their gatherings, graduates devoted their time to various cultural activities such as acting, debating and writing poetry..$^{26}$ At other times they would assign to one of the members to prepare a topic for discussion and answer the questions coming from the available audience. Their cultural contribution was also extended to writing in the British and Egyptian press, seen in their published articles that carried patriotic sentiments. ${ }^{27}$ The most important literal societies emerged in the urban side of Sudan, particularly the National City of Omdurmanthat accommodated some remarkable literal societies, one of which was the society of $A b u$ Ronf which took its definite form in 1928-1929..$^{2 s}$ 
As mentioned in some relevant sources it was accorded this name because most of its founders lived in Abu Roaf in Omdurman. ${ }^{29}$ This society was initiated by the two brothers Hassan and Hussein Al-Kidd who were joined by a group of Gordon's college graduates like Khidir Hamad, Ismail Al-Atabani and other devoted nationalists. Most of the $A b u$ Roaf members were allegedly graduates of Gordon College in the first decade that followed the 1924 movement when they also experienced the severe blow given by the British administration to the educated elite. This was something that tremendously shaped their pro Egyptian thoughts, as during that phase they were extensively reading Egy ptian journals and books which they received from Egyptian dealers."

They were also fond of Egyptian nationalists, particularly the Wafd party and believed that Egypt was the focal point of Arab enlightenment, ${ }^{31}$ as members of the Abu Roaf group resented all sorts of non-Arab ties for the Sudanese and believed that Sudan was part of the Arab Islamic world. At the beginning, the main concern of this society was reading thence it established a reading society in which its members read old and modern fictions, as well as political books. Their readings were also extended to Fabian and leftist books since they joined the left book club which provided to them its issued books and journals on a monthly basis. Another literal society which had its foundations in Omdurman was the Al-Fajr group which was also known as the Hashmab with its founders mainly from the inhabitants of Al-Morda and Al-Hashmah districts. It included graduates of the Gordon college like Mohammed Ahmed Mahgoub and Abdel Halim Mohammed in addition to talented writers like Arafat Mohammed Abd Allah who, in 1924, managed to establish the Al-Fajr magazine - literally means ' the dawn'. This magazine attracted the graduates to publish in its pages literal and political topics which were of recognizable impact in spreading modern Sudanese nationalism. ${ }^{32}$

Unlike members of the Abu Roaf group who were originally from families that had genuine ties with the Khatmiyya sect, Al-Fajr or Hashmab members originated from families that were formerly involved in the Mahdist regime and occupied important posts during its era of rule. ${ }^{33}$ Since the commencement of their literal society, the Hashmab group members concentrated on issues of social nature, where they also emphasized on education and its importance, expansion and the need for higher education. Although they occupied themselves with educational issues, the Al-Fajr society had also national and political aspirations. ${ }^{34}$ The declared policy of al-Fajr was completely ad vocative of anti-tribal sentiments and for the most part, encouraged a policy of resenting indirect rule. Its members also believed in the Sudanese nationalism, 
self-government and they never praised or accepted the pro Egyptian policy. Due to their intellectual and philosophical readings, the Al-Fajr group became largely influenced by the Western culture and nationalism as presented by western philosophers, thus they called for Sudan to be completely independent from Britain and Egypt. ${ }^{35}$

A third literal society that originated in Omdurman was the Ashiqqa. They were mainly relatives, blood brothers and friends who had strong ties, and they lived in Omdurman's districts of Al-suq and al Bousta. The society was formed in 1931 by Yahia al Fadli, Mahmoud Al-Fadli, Hassan Yassin, Alımad Yassin, Shadad, al-Qabbani and had Sayyid Ismail Azhari as their president. Although their concerns were mainly literal, Al-Asigqa had also political interests which led them to take full control of the Graduates' club committees. At the beginning of its formation, the group had thought splendidly about the Shangists and Sayyid Abd Al-Rahman Al-Mahdi with whom they had strong ties; however their inclination for Egypt and their adoption for unionist ideas had ended that magnificent relationship..$^{36}$

In addition to the literal societies which were held in Omdurman there was the Wad Medani literal society which drove its name from the city of Wad Medani where it was situated. The group was founded in 1936 by a group of graduates who were formerly active in the Abu Roaf group and moved to Wad Medain to comply with their governmental duties. ${ }^{37}$ Members of this group who included Ahmad Khayr, Ibrahim Osman Ishaq, Ismail Atabani, Hassan Osman Nour, Anis Mansour and others, met weekly to hold literal activities like reading, writing and making theatrical performances. They were also informed about the aspirations of nationalists elsewhere and were knowledgeable about their movements in Africa and Asia, where most of them appreciated the success of the Asian nationalism. Such a growing appreciation had encouraged their call for the rise of the Graduates' General Congress upon the style of the Indian congress, as it will be clarified later. In the period of 1925-1936, literal societies played a significant role in broadening graduates' knowledge, ${ }^{36}$ where they increased their understanding for the political situation in Sudan and facilitated graduates' participation in the national issues of their country. As a result of their effectiveness in spreading national and political knowled ge among graduates, literal societies produced recognizable types of political and social attitudes that dominated Sudanese politics afterwards.

\section{The Establishment of the Graduates' General Congress}

By the mid-nineteen thirties Graduates of Gordon college and other schools began to feel the need for organizing themselves in order to be 
able to stand against the challenges facing the Sudanese people who were then completely suffering under the colonial administration. However, their efforts to organize themselves were accelerated as a result of signing the 1936 treaty ${ }^{39}$ between Britain and Egypt, which, due to its course, the Sudanese were allowed limited participation in the rule of their country while all the sovereignty matters in Sudan were to remain under the control of condominium administrators. Throughout the period between 1936-1937, Sudanese intelligentsia became more involved in national campaigns in order to threaten or at least disturb this treaty. Therefore, the educated elite became active at the Graduates' Club in Omdurman, sub graduates' clubs and literal societies in which they discussed the concurrent conditions in Sudan, as well as its destiny. ${ }^{40}$

In addition to this, they continued to pursue the spread of national sentiments ${ }^{41}$ through lectures in which their gracious leaders spoke consistently about national movements in the Arab world as well as Asia, particularly India. The Indian national combatants like Mahatma Gandhi and Jawaharlal Nehru had sampled the model or the example that the graduates had idolized. The concrete call to form a graduates' organization was displayed in a lecture given by Ahmad Mohammed Khayr at the staff's club in Wad Medani on the 16th May 1937. The lecture which was named Wajibuna Al-Syyasi bad Al-Muahada - literally meaning our political duty after the agreement - confirmed that it is the national duty of the graduates to revolutionize against the ridiculing method of the colonial rule and to threaten its administrative law that endorsed indirect rule. He then called for demonstrations against monopoly firms, fiscal and education systems. Ahmad Khayr urged the graduates to organize themselves in a league, congress or union centered in the Omdurman club committee with branches in the rural areas. ${ }^{49}$ The speaker assumed that if the graduates spread their national program, then they could claim that they figured and defined their political duties. ${ }^{42}$

Although some graduates were fond of the Egyptian nationalists, particularly members of the Waft party, their inclination to establish the emerging graduates' organization on an Egyptian style did not compete with the arising idea of imitating the Indian style. At the time of initiating the Congress, most of the Graduates were quite impressed by the Indian nationalism, particularly the Indian National Congress. As stated by Afaf Abu Hasabu "Ahmad Khayr had in mind an association along the lines of the Indian Congress movement, its leaders Ghandi and Nehru and the writings of Krishna Menon in defense of the Indian case"..$^{43}$ Khayr also aimed that the Congress would become the body, to which the Government referred to whenever it wanted to consult the opinion 
of the educated public and that through time the Congress- being the example of educated people - would become Sudan's sole spokesman in matters concerning its national and political entity ${ }^{44} \mathrm{His}$ call for the rise of the Graduates' General Congress was admirably received by the educated elite that subsequently formed a preliminary committee from members of the Graduates' club in Omdurman, to follow up the initiation of this important organization. ${ }^{45}$

The first decision of this preliminary committee was the instigation of a weekly seminar in which the graduates would speak about their perception for the specialization and work of the Graduates' General Congress which was planned to be implemented. The Graduates' ideas about the congress were diverse since they included cultural, social, economic and political aspects, whereby at the committee the graduates also discussed if the Congress would be a complete picture of the Indian National Congress or it would vary. In their deliberations at the preliminary committee, the graduates resented tribalism and sectarianism assuming that this would strengthen the congress' commitments to Sudanese nationalism and allow it to become a strong national front that would stand against difficulties. ${ }^{46}$ In addition to the preliminary committee smaller committees were established to consult senior members of the Graduates' club and ask them to participate in the formation of the Congress. Their efforts ended successfully since most of the Graduates' club members from the Sharugists and Feelists were willing to rejoin and became involved in the initiation of the congress. On $14^{\text {th }}$ February 1938 , one thousand one hundred and eighty graduates held a meeting at the Graduates' club in Omdurman, under the chairmanship of Ismail Azhari. ${ }^{47}$

After the assembly approved the Congress' brief constitution ${ }^{48}$ which contained seven items and declared its objectives as The promotion of the general welfare of the country and the graduate. Being keen to receive the authenticity for national work members of the Graduates' General Congress sought the government's consent for their initiated congress in order to avoid being treated as a secret society; something which might lead to the graduates' interrogation. ${ }^{49}$

On the $2^{\text {nd }}$ May 1938 the government which had prior information about this meeting approved of registering the Congress as a philanthropic group that had social ties and educational concerns, and refused to register it as a political organization. ${ }^{50}$ Throughout its initial phase the Congress consolidated its work on the social and educational fields since its members aimed for gaining peoples' acknowledgment in order to secure its recognition as an important political institute among the Sudanese. ${ }^{51}$ On the social level the Congress fought against bad habits which were spread in the poor districts in urban Sudan; those 
of which included like liquor consumption, prostitution, gambling; pertaining to this, the Graduates' General Congress had also succeeded in preventing the consumption of alcohol in national clubs. However, the most important activities held by the Congress were in the field of education. The period between 1938-1946 witnessed a great expansion in education and the establishment of educational institutes, particularly the community education, where the Graduates' General Congress raised special funds in order to meet its expenses. ${ }^{52}$

In addition to a recognizable day known as the educational day that was established in 1941, the reason behind its initiation was to support the spread of education, as well as winning the Sudanese people's support for the Congress and making they become better acquainted with its activities. This spread of education among the Sudanese people had brought the Congress enormous support especially with the formation of a committee to investigate the education system run in the Northern and Southern Sudan. It recommended that ed ucation should become possible for the entire nation and for those in the age deemed suitable to obtain knowledge. In order to facilitate the consolidation of its works, the Graduates' General Congress attempted strengthening its relations with Egypt which was at the begging suspicion about the Congress' intentions. Therefore the Congress seized the opportunity of Egypt's Prime Minister Ali Mahir's visit to Sudan and asked the government to allow them to entertain him and the following delegates. Despite the fact that the administrators gave permission for a limited party, the Congress held a capacious gathering at the graduates' club in Omdurman in which the Egyptian visitors were heartily welcomed and the receiving crowd called for the Sudanese and Egy ptian welfare. ${ }^{5.3}$

As mentioned in the above lines, the Graduates' General Congress utilized the gathering to inform the Egy ptian dignitary Ali Mahir Pasha , about the nature of the Congress' work and to ask for the Egyptian support to its designated social reforms, exceeding by this any deliberations with the British administrators. ${ }^{54}$ As stated by Alexander Cudsi the overall effect of the tea- party was far-reaching. It restored to the Congress its lost prestige and gained for it in the urban circles and in the press, recognition and a distinction it had never enjoyed before. The affair also convinced some Egyptians that the Congress was in fact the embryo of a genuine Sudanese nationalist movement in which Egypt had to take a sympathetic interest and which she had to court as a potential ally in the pursuit of her claims. The door was thus, opened between the Egyptians and the Congress - contacts which were destined to play a very crucial role in later years. ${ }^{55}$

This pro-Egyptian attitude, as well as the graduates' endeavoring for involvement in politics, had triggered some British resentment and 
attempted to block the Graduates' General Congress activities. As a result of the administrations' prosecutions, the Congress' executive committee stopped collaboration with the colonial administrators in Khartoum and started to advocate the Graduates' General Congress' participation in the political sphere. This enrollment in politics, soon led the Congress members to think of informing the government about their points of view in the ongoing administrative and governmental situations in the country. ${ }^{56}$ The peculiar event that followed the Congress' consideration to participate in politics was the sending of the Graduates' General Congress memorandum to the Sudan's Governor - General on the $3^{\text {rd }}$ April 1942. The memorandum included twelve points that resembled the Sudanese people's request in general and the Graduates' in particular; members of the Graduates' General Congress demanded the following from the colonial administration in Sudan:

1. The issue, on the first possible opportunity by the British and Egyptian governments, of a joint declaration, granting the Sudan in its geographical boundaries, the right of self-determination, directly after the war; this right was to be safeguarded by guarantees assuring full liberty of expression in connection therewith; as well as guarantees assuring the Sudanese the right of determining their natural rights with Egypt in a special agreement between the Egyptian and Sudanese nations.

2. The formation of a representative body of Sudanese to approve the budget and the ordinance.

3. The formation of a higher Educational Council, composed of a Sudanese majority, and the minimum of 12 percent of the budget proposed to be devoted for education.

4. The separation of the judiciary, from the Executive, body.

5. The abolition of ordinances on closed areas, and the lifting of restrictions placed on trade and on the movements of the Sudanese within Sudan.

6. The promulgation of legislation defining Sudanese nationality.

7. The termination of immigration, except within the limits agreed upon in the Anglo-Egyptian Treaty.

8. The termination of the Sudan plantations Syndicate contract at its expiration.

9. The carrying out of the principle of the Sudanese welfare and their priority to the Government posts as follows:

(a) By giving the Sudanese an opportunity to share effectively the ruling of the country; this is to be attained by the appointment of Sudanese in posts of political responsibility in all the main branches of the Government. 
(b) By limiting the appointments of Government posts to Sudanese.

With regards to the posts for which it is necessary to appoint non-Sudanese, they shall be filled with persons serving on definite term contracts; in the meantime, the Sudanese are to be trained to fill the posts at the expiration of the contract.

10. The Sudanese are to be enabled to exploit the commercial, agricultural and industrial resources of the country.

11. The promulgation of an ordinance imposed on companies and commercial firms the obligation of reserving a reasonable proportion of their posts for the Sudanese.

12. The cancellation of subventions to missionary schools and the unification of syllabus in the Northern and Southern Sudan. ${ }^{57}$

The Congress memorandum which had apparently revealed patriotic sentiments, such as self- determination, Sudanese - Egyptian relations, the rise of a legislative assembly, unification of Northern and Southern Sudan as well as the Sudanization of posts, had been unadvocated by colonialists. The memorandum was coolly received by the British administrators in Khartoum; although this could be referred to various reasons, it is worth noting that the consolidation for the pro Egyptian attitude was probably the most resented. The British administration represented in the civil secretary Sir Douglas New bold sent a harsh letter to the Grad uates' General Congress president. In his letter, he stated that the Condominium administration was the only officials allowed dealing with the constitutional issues, and that the Congress was not yet entitled any political rights. The government's harsh attitude towards the memorandum had a strong impact upon the graduates' ties with the government, since it resembled the first sign of collapse of the relationship that was once strong. The rejection of the memorandum also brought some breakage in the links among graduates, especially when the government started to urge for the rise of the advisory council of Northern Sudan. Some graduates considered this act as a method to prohibit the development of Sudanese nationalism. Therefore, the graduates split into two factions; some moderates led by Ibrahim Ahmad assumed that partaking in the council would allow them to present through time their national points of view, which was concisely upholding the 'Sudan for Sudanese' notion.

The other group led by Ismail Azhari congregated around a boycott philosophy for the governmental institution; this group which later formed the Ashiqqa party had its views and dimensions quite dominant upon the Congress and its activities. However, both the Ashiqqa and 
the Umma party or those who surrounded upon the philosophy of the Sudan for Sudanese, were among the parties that advocated Sudan's independence after it was granted the rights for self-government and self-determination in $1953 .{ }^{58}$ Both graduates had members from the Graduates' movement which developed through time as an important movement that had a say in deciding over Sudan's destiny.

\section{Conclusion}

The above summary was an attempt to study the emergence and development of the graduates' movement in Sudan in the period between 1918 1944. The investigation of the available data reveals that the Graduates' movement had developed in Sudan as a result of the rise of the educational institutions. That provided the Sudanese students with literal information, namely languages. This linguistic knowledge enabled the graduates to be acquainted about world politics and nationalism elsewhere. Being impressed by the ongoing nationalism particularly in Egypt and India, Sudanese graduates soon became involved in political activities that first took the military form and later displayed itself in a more subdued form, in order to avoid the aggression of the colonial administration.

The second phase of the Sudanese Graduates' struggle against colonialism was first exhibited in the consolidation of the Graduates' national and political knowledge, which was fully developed as a result of the initiation of the literal societies. Graduates' gatherings in literal societies also worked as an antidote for the tribal system which was enlivened by the Colonial administration as a result of applying indirect rule that vested all the authorities in the hands of tribal chiefs. As a result of their organization in literal societies, Nationalists from among the graduates were also enabled to rise against the manipulative policy of the colonial administrators, particularly after the signing of the 1936 treaty that deprived the Sudanese of an exercise of any power in their own country. The nationally cautious educated elite soon left their literal societies to establish more organized and unifying union; their efforts culminated in the formation of the Graduates' General Congress which was established on the $12^{\text {th }}$ February 1938.

The Graduates' General Congress which developed into a prominent entity in the first four years of its initiation managed to defy a lot of the anomalous administrative practices and policies of the administrators. The first was through establishing sound reputation among the Sudanese people by providing philanthropic support winning by this their backing for the Graduates' General Congress as a national institution. Secondly by the issuance of its eminent 
memorandum in April 1942 a remarkable event which brought their side the British recognition and their permission for the organization of the political parties that collaborated to support Sudan's independence on the $1^{\text {st }}$ January.

\section{Notes}

1 Ahmad Khayr, Kifah jil, Khartoum: Al-Dar Al-Sudaniyya lil Kutub, second edition, 1974, p. 19.

$2 \quad$ lbid.

3 One of the first established Sudanese newspapers which appeared for the first time in 1919, See Mahgoub Mohammed Salih , Al-Sahafa AI-Sudaniyyia fi nisf Qarn, Khartoum: Khartoum University Press, 1970, pp. 22-28.

4 A Graduate of Gordon Memorial College who had a prominent position in the Graduates' club in Omdurman, See Moutasim Ahmad Elhaj, Moujaim Shaksyat Moutanimar Elkhirijin, Omdurman : Markaz Mohammed Omer Beshir, 2001, p. 118

5 Ahmed Mohammed Yassin, Mudhakkirat Alımed Mohammed Yasin, Omdurman : Markiz Mohammed Omer Beshir, 2001, pp. 70-180

6. Afaf Abdel Majid Abu Hasabu, Factional Conflict in the Sudanese Nationalist movement 1918-1948, Khartoum : Graduate College University of Khartoum, 1985, p. 34.

$7 \quad$ Ibid., pp. $39-40$.

8 The best example for this was their accordance for the president Wilson's principles which called for granting harassed nations the right for self determination, See Ahmad Khayr, Kifah jil , pp. 48-49.

9 Selma Bot man, Egypt from Independence to Revolution, Syracuse, NY: Syracuse University Press, 1991, pp. 25-26.

10 Shawgi Ata Allah Al-Jamal, "Athar thawrat 1919 fi Misr ala thawrat 1924 fi Al-Sudan" in Mahasin Abd AI-Qadir Haj Al-Safi (ed.), al-Haraka AlWataniyya fi Al-Sudan: Thatorat 1924, Khartoum : Khartoum University Press, 1992, pp. 114-158.

11 Obaid Haj Al-Amin was a graduate of Gordon Memorial College and served as a translator in the post and telegraph department. See Hassan Najila, Malamih min Al-Mujtama Al-Sudani, Beirut: Dar Maktabat Al-Hayat, 1964, pp. 154-164.

12 Ali Abdel Latif 1892- 1948 was from the Dinka origin that graduated from the military school, joined the Egyptian army and lived in Egypt. He supported unity with Egypt and insisted on confronting the British, the thing which led to his imprisonment. See Mohammed Shafiq Qurbal, Al-Mousa Al-Al-Arabiyya Al-Mouisarra, Cairo: Dar Alshiab, 1959, p. 1617.

13 Hassan Najila, Malamilt min Al - Mujtama Al-Suddani, p. 203-206.

14 The ninth ruler of Mohammed Ali Pasha dynasty during his 9 years period of reigning Egypt became a kingdom and he was named the King of Egypt and Sudan, See http:// answers.com/topic/fuad 1-of Egypt. 10, January, 2012 
15 Mohammed Omer Beshir, Tarikh Al-Haraka Al-Wataniyya fi Al-Sudan 19001969, Beirut: Dar Al-Jil, 1987, p.109.

16 Ibid.

1. Martin Daly, Empire on the Nile: The Anglo- Egyptian Sudan1898-1934, Cambridge: Cambridge University Press, 1986, pp. 294-297.

18 Heather Sharkey, Liong witl Colonialism Nationalism and Culture in the Anglo Egyptian Sudan, California: California University Press, 2003, p.78.

19 Hasan Abdin, Early Sudanese Nationalisn 1919-1925, Khartoum : Khartoum University Press, 1985, p. 37

20) Heather Sharkey, Living roith Colonialism, p. 78.

21 Mohammed Ahmed Mahgoub and Abdel Halim Mohammed, Morot Dunia-Cairo: Matbat Akhbar_Alioum, 1946, p. 100.

22 Abdel Rhman Al-Faki, Tarikh youal Difa Al-Sudam, Khartoum: Al-Dar AlSuddaniyya lil Kutub, 1971, p. 105.

23 Heather Sharkey, Lioing with Colonialism, p. 81.

24 Mohamed Omer Beshir, Tatwar Al-Talim fi Al-Sudan 1898-1956, Beirut: Dar Al-Jil, 1983, pp. 97-119.

25 Afaf Abdel Majid Abu Hasabu, Factional Conflict, p. 52.

20 Ahmad Khayr, Kifall,jil, pp. 58-59.

27 Gassim Osman Nur, Al-Madaris Al-Fikkrya wa Al-Jamyat Al-Adabya wa dwarhua fi Al-Harakah Al-Watanyyia AI-Sudanyyia' B.A. Dissertation, University of Khartoum, Sudan, 1988, pp. 60-65.

28 Ibid., p.66.

29. Afaf Abdel Majid Abu Hasabu, Factional Conflict, p. 52

30. Khidir Hamad, Mudhakkirat Khidir Hamad: Al-Haraka Al-wataniyya AlSudamiyna Al-istiqlal wa-na budahn, Al-Shariqa, 1980, p. 29.

31 Ahmad Mohamed Yasin, Mouzakirat Almmad Molanted Yasin, Omdurman: Markiz Mohamed Omer Beshir, 2001, p.16.

32 Afaf Abdel Majid Abu Hasabau, Factional Conflict, p. 53.

33 The Hashmab were completely recognized during the Mahdist era, among the most prominent was Shayakh Abul Gasim, See Richard Hill, The Biographical Dictionary of the Sudan, London: Frank Cass, 1967, p. 23.

34 Afaf Abdel Majid Abu Hasabu, Factional Conflict, p. 54.

35 lbid

36. Hassan Ahmed Ibrahim, Sayyid Abdel - Rhman Al-Malndi A Study of neo Maludism in Sudan 1899-1956, Leiden: Brill, 2004, pp. 149-159.

3 Duria Abd Allah Mirghani, Abd Allah Mirghani Ahad Rovad Al-Harakah Al-Watanyyia fi Al-Sudan, Khartoum: Dar Jamyat Al-Quran Al-Karim Iil Tiba, 1999 , p.40.

38 lbid., p. 41

39. Interview with Dr. Abdel Halim Mohammed. Member of the Graduates' General Congress fifth executive committee, at his residence in Khartoum $23^{\text {rd }}$ December 2003.

40 Ahmad Khayr, Kifal jil, p. 80.

41 Muddathir Abdel Rahim, Inperialism and Nationalisn in the Sudan: A Study in Constitutional Es Political Decelopntent 1899-1956, 3rd editions, Khartoum: Khartoum University Press, 1990, p. 112. 
$42 \quad$ Al-Faiir, 16 May 1937.

4. Afaf Abdel Majid Abu Hasabu, Factional Conflict, p. 76.

44 Ahmad Mohammed Yasin, Mouzakirat Ahmed Mohammed Yasin, Omdurman: Markaz Mohammed Omer Beshir, p. 67.

45. Al-Fajir, 16 May, 1937

46 Khidir Hamad, Khidir Hamad, pp. 83-84.

47 Sudanese teacher and a graduate of the American University of Beirut, Azhari was a prominent member of the Graduates' club and later the Graduates' General Congress. In 1954 he became the first Sudanese Prime Minister, See Moutasim Ahmad Elhaj, Moujaim Shakhsyat , p. 41.

$48 \quad$ Ahmad Mohammed Yasin, Mudhakkirat, pp. 72-76.

49 Www.alsahafa.sd/details.

50 Mahgoub Omer Bashiri, Malamilh min Al-haraka Al-Wataniyyia, Beirut: AlMaktabah Al-Wataniyyia, 1996, pp. 134-136.

51 Ahmad Khayr, Kifah jil, pp. 100-150.

52 Moutasim Ahmad Elhaj, Mahadir Moutannar Elkhiriin, volume 1, pp. 54 53 Ahmad Mohammed Yasin, Mouzakirat, pp. 81-84.

54 Ibid.

55 Alexander Cudsi, "The rise of the Political Parties in Sudan 1936-1946", p. 121.

56 Kenneth David Druitt Henderson, Kaif ayid Al-Sudan Al-Hadilh hyat wa Moursalat Al-Sir Douglas Newbold, volume 2 section 3 translated by Mahmoud Salih Osman Salih, Omdurman: Markaz Abdel Karim Mirghani, 2010, pp. 164-166.

57 Members of the executive committee sent a memorandum to the Civil Secretary New bold, establishing their regret for not being informed about the sending of the Sudan's military forces to war, See Moutasim Ahmad Elhaj, Mahadir Moutammar Elkhirijin, volume 1, p. 228.

58 Alexander Cudsi 'The rise of the Political Parties in Sudan 1936-1946', pp. 295-298. 